\title{
KONFLIK BATIN TOKOH "AKU" DALAM NOVEL GARIS WAKTU KARYA FIERSA BESARI
}

\author{
Hadi Rumadi $^{1}$, Syafrial ${ }^{2}$, Sri Wulan Fajriani ${ }^{3}$ \\ Universitas Riau, Pekanbaru, Indonesia ${ }^{1,2,3}$ \\ hadirumadipbsi@gmail.com ${ }^{1}$,syafrialpbsiunri@gmail.com² \\ sriwulanfajriani2019@gmail.com ${ }^{3}$
}

\begin{abstract}
The inner conflict is a part of the prosaic objectivity elements that are inherent in the characters, especially novels. It occurs as the attraction of the story so that the values of ethics and personal values are illustrated that can be enjoyed. Internal conflict as a reflection of the fact of humanity that is always faced by anyone, does not rule out the possibility of figures contained in literary works. With its existence makes the story more alive and meaningful with all events in it. The focus of inner conflict in this novel is the perspective of the first person 'I', the author of the novel himself, Fiersa Besari. So, this study aimed to describe the inner conflict on the character "I" in Garis Waktu novel written by Fiersa Besari. It was a qualitative study that used a descriptive-analytical method. Garis Waktu Novel was used as a source of data. Identification, description analysis, discussion, and conclusions were applied to analyze the data. The results were the personal life of the character 'I' through psychoanalytic studies. His personal life did not merely apply because of the personality concept as a writer, all the inner conflicts that occurred also related to the social external concepts of characters, where there was an involvement of other people in creating inner conflicts within the character. The conclusion is the inner conflict faced which is a form of emotional overflow that occurs because the elements in themselves are influenced by external elements, so as a character often this inner conflict is a part of personality that cannot be avoided by humans themselves, including the figure of Fiersa Besari.
\end{abstract}

Keywords: inner conflict, novel, psycho-analysis

\begin{abstract}
ABSTRAK
Konflik batin tokoh adalah bagian dari unsur objektivitas prosaik yang melekat pada tokoh-tokoh cerita khususnya novel. Konflik batin terjadi pada tokoh sebagai daya tarik cerita agar nilai-nilai esetetika dan nilai personalitas tergambar yang dapat dinikmati oleh pembaca. Konflik batin sebagai cerminan fakta kemanusiaan yang selalu dihadapi oleh siapa saja, tak menutup kemungkinan tokohtokoh yang terdapat dalam karya sastra. Dengan adanya konflik batin menjadikan cerita lebih hidup dan bermakna dengan segala persitiwa di dalamnya. Fokus konflik batin dalam novel ini adalah sudut pandang orang pertama 'aku' yaitu si pengarang novel sendiri; Fiersa Besari. Rumusan masalah yaitu bagaimanakah konflik batin tokoh "Aku" dalam novel Garis Waktu karya Fiersa Bersari?. Tujuan ialah mendeskripsikan konflik batin pada tokoh "aku" pada novel Garis Waktu karya Fiersa Besari. Jenis penelitian ini merupakan jenis penelitian kualitatif. Metode penelitian yakni deskriptif analitis. Teknik pengumpulan data ialah dokumentasi. Sumber data yang yakni dari novel Garis Waktu karya Fiersa Besari. Data berupa dimensi kewacanaan berupa kalimat-kalimat dialog tokoh dalam novel. Teknik analisis data ialah identifikasi, analisis deskripsi, pembahasan, dan kesimpulan. Hasil berupa temuan data yang didapat dari isi cerita pada novel Garis Waktu. Penggunaan kajian psikoanalisis pada novel ini sangat pantas untuk diteliti, karena isi cerita pada novel ini juga berupa konflik batin yang selalu terjadi pada tokoh "aku" yang menceritakan tentang kehidupan pribadi tokoh "aku". Kehidupan pribadinya tak semata berlaku karena konsep personalitas Fiersa Besari sebagai penulis, segala konflik batin yang terjadi juga berkaitan dengan konsep eksternal sosial tokoh, di mana adanya keterlibatan oranag lain dalam menciptakan konflik batin dalam diri tokoh. Simpulan adalah bahwa konflik batin yang dihadapi oleh tokoh merupakan
\end{abstract}

Konflik Batin Tokoh "Aku” dalam Novel Garis Waktu Karya Fiersa Besari 
bentuk peluapan emosional yang terjadi karena unsur dalam dirinya sendiri yang dipengaruhi oleh unsur luaran, sehingga sebagai tokoh acapkali konflik batin ini adalah bagian personalitas yang tak dapat dihindari oleh manusia itu sendiri, termasuk tokoh Fiersa Besari.

Kata Kunci : konflik batin, novel, psiko-analisis

\section{PENDAHULUAN}

Novel merupakan karya sastra genre prosa yang merupakan cerita fiksi dan dituangkan melalui tulisan. Novel biasanya berisi kehidupan manusia dengan sesamanya. Novel mempunyai unsur ekstrinsik dan intrinsik. Biasanya, seorang pengarang berupaya membawa seorang pembaca kepada potret kenyataan melalui isi cerita yang terdapat dalam novel tersebut. Novel banyak beredar dan termasuk karya sastra yang paling popular di dunia.

Sebagai karya prosa, novel mengisahkan serangkaian cerita yang selalu memiliki awal dan akhir. Cerita ini diperankan oleh aksen yang disebut dengan tokoh. Salah satu yang menarik adalah tokoh memainkan peran lengkap dengan karakter yang dimiliki. Karakter ini sebagai salah satu unsur intrinsik yang mampu mencerminkan sikap baik dan buruk tokoh cerita.

Sebagai tokoh yang memiliki karakter, tentu saja berkaitan dengan kondisi psikis atau jiwa tokoh itu sendiri. Jiwa tokoh memainkan peranan penting sebagai refleksi kehidupan nyata. Peran penting ini selalu mengalami suatu peristiwa kebatinan atau konflik batin tokoh. Konflik batin menyiratkan serangkaian permasalahan yang dihadapi tokoh, sehingga alur peristiwa yang terjadi semakin jelas dan menarik.

Konflik batin tokoh menarik untuk diteliti dalam satu kajian ilmiah. Keberadaan konflik batin ini memicu terjadinya peristiwa cerita semakin menarik. Konflik batin dapat saja terjadi secara personal maupun antarpersonal. Umumnya hal tersebut terjadi akan menambah nilai estetika cerita. Dalam prosa khususnya novel, keberadaan konflik batin kerap kali dialami oleh tokoh-tokoh cerita yang bertitik tolok pada unsur objektivitas cerita yaitu alur, watak, tema, setting dan unsur-unsur lainnya.

Unsur-unsur objektivitas tersebut akan menciptakan konflik batin yang begitu sederhana atau begitu rumit. Sederhana atau rumit ini dialami oleh tokoh secara personalitas dalam upaya menyelesaikan masalah kebatinan tersebut. Hakikatnya, sebagai suatu karya fiktif imajinatif, novel akan menyajikan serangkaian peristiwa kebatinan yang begitu menarik guna membuat pembaca terkesan akan cerita tersebut.

Tokoh dalam cerita umumnya terdiri atau tokoh orang pertama dan orang ketiga. Tokoh orang pertama menggunakan kata "aku" sedangkan tokoh orang ketiga menggunakan nama samaran. Novel Garis Waktu (selanjutnya disingkat GW) menggunakan tokoh orang pertama tunggal, yaitu 'aku', karena pengisahan terjadi pada di si penulis sendiri. Polemik personalitas kebatinan ini menjadi isi novel yang menarik ditelaah melalui kajian psikoanalisis.

Fiersa Besari adalah penulis novel GW. Selain seorang penulis, Fiersa juga seorang pemusik. Sebagai penulis, Fiersa telah menghasilkan enam novel. Ia juga terlibat sebagai salah satu pendiri komunitas Pecandu $B u k u$. Di bidang musik, Fiersa Besari memulai kariernya justru sebagai vokalis band Indie. Jelas sekali dunia kepenulisan dan musik merupakan saling keterkaitan dalam jiwanya. Umumnya karya-karya Fiersa banyak disenangi oleh kaum muda, ini berkaitan dengan sifat karyanya yang lebih realistis akan pemberontakan-pemberontakan jiwa yang selalu dialami oleh kaum muda, sehingga tulisan Fiersa dianggap sebagai representasi dari perasaan mereka.

Berdasarkan latar belakang, maka rumusan masalah penelitian ini adalah bagaimanakah konflik batin tokoh 'aku' dalam novel Garis Waktu karya Fiersa Besari?. Tujuan penelitian ini adalah mendeskripsikan konflik batin tokoh 'aku' dalam novel Garis Waktu karya Fiersa Besari. Sementara manfaat penelitian ini adalah dapat secara teoretis dan praktis. Secara teoretis sebagai pengayaan referensi teori sastra mengenai unsur struktur

Konflik Batin Tokoh "Aku” dalam Novel Garis Waktu Karya Fiersa Besari 
karya dalam novel aspek batin tokoh, sedangkan manfaat praktis sebagai wadah refleksi diri dalam mengambil keputusan baik pembaca dalam adat bertingkah laku di masyarakat. Refleksitas nilai-nilai kebaikan ini didapati dari karya sastra yang disebut dengan novel.

Menurut Nurgiyantoro (2010) novel berasal dari bahasa Italia yakni novella yang berarti sebuah barang baru yang kecil, dan kemudian diartikan sebagai 'cerita dalam bentuk prosa'. Dewasa ini istilah novella mengandung pengertian dengan istilah Indonesia 'novelette' (Inggris), yang berarti sebuah karya prosa fiksi yag panjangnya cukupannya, tidak terlalu panjang, namun juga tidak terlalu pendek.

Selanjutnya, Nurgiyantoro (2010) juga mengemukakan bahwa novel adalah media penuangan pikiran, perasaan, dan gagasan penulis dalam merespon kehidupan disekitarnya. Ketika di dalam kehidupan muncul permasalahan baru, nurani penulis novel novel akan terpanggil unntuk segera menciptakan sebuah cerita. Segi panjang cerita, novel (jauh) lebih panjang daripada cerpen. Oleh karena itu, novel dapat mengemukakan sesuatu secara bebas, menyajikan sesuatu secara lebih banyak, lebih rinci, lebih detil, dan lebih banyak melibatkan berbagai permasalahan yang lebih kompleks.

Menurut Zaidan, dkk (2007), menyatakan bahwa novel adalah jenis prosa yang mengandung unsur tokoh, alur, latar rekaan yang menggelarkan kehidupan manusia atas dasar sudut pandang pengarang, dan mengandung nilai hidup yang diolah dengan teknik kisahan dan ragaan yang menjadi dasar konvensi penulisan. Pergolakan batin dalam cerita sebenarnya menjadi ciri khas tersendiri yang dapat dicermati oleh pembaca. Di dalam batin itu ada jiwa, jiwa ini mengisi setiap tokoh dalam cerita.

Menurut Dewi (dalam Nugroho dkk 2019), Mengatakan bahwa konflik batina adalah suatu permasalahan yang berhubungan dengan jiwa seseorang yang disebabkan perbedaan dan pertentangan sehingga memengaruhi tingkah laku seseorang atau tokoh tersebut. Konflik dalam karya sastra seperti halnya novel, menjadi sangat penting guna membangun dan mengembangkan alur di dalamnya. Berfungsi untuk menumbuhkan pengenalan nilai atau pesan dan bahkan bisa pada tahap karya sastra tersebut mampu membentuk sebuah replikasi kehidupan manusia yang pada umumnya akan menemui konflik-konflik kehidupan.

Karya sastra berkaitan dengan konsep psikologi, sehingga dalam kajian ini disebut dengan psikologi sastra. Konsep psikologi sastra melibatkan aspek kejiwaan tokoh yang dinaratifkan secara prosaik. Woodworth dan Marquis (dalam Walgito, 1997) memberikan gambaran bahwa psikologi itu mempelajari aktivitas-aktivitas motorik, kognitif, maupun emosional. Oleh karena itu berdasar konsep itu, psikologi sastra merupakan konsep kejiwaan tokoh yang diterapkan melalui karya sastra genre prosa.

Menurut Sangidu (dalam Husnah dkk, 2019:63), Mengemukakan bahwa psikologi sastra adalah suatu disiplin yang menganggap bahwa sastra memuat unsur-unsur psikologi. Psikologi sastra mengkaji tentang sisi lain dalam kehidupan manusia yaitu pada aspek kedalaman jiwa manusia.

Sementra itu, Rokhmansyah (dalam Husnah dkk, 2019:63), Menjelaskan bahwa Freud mengemukakan bahwa struktur kepribadian manusia mengandung tiga komponen yang disebut id (tidak sadar), ego (tidak sadar, prasadar, sadar), dan superego (tidak sadar, prasadar, sadar). Sementara menurut Endaraswara (dalam Hartati, 2019), psikologi sastra adalah kajian sastra yang memandang karya sebagai aktivitas kejiwaan. Psikologi sastra berkaitan dengan psikoanalisis. Psikoanalisis adalah bagian dari psikologi kepribadian. Teori psikoanalisis yang dicetuskan oleh Freud menyatakan bahwa perilaku manusia dibentuk oleh nalurinaluri dan konflik-konflik struktur kepribadian. Konflik-konflik struktur kepribadian ialah konflik yang timbul dari pergumulan antara id, ego, dan superego( Minderop dalam Miyasari 2018).

Psikoanalisis merupakan sebuah teori yang berupaya untuk menerangkan dasar dan perkembangan karakter manusia. Minderop (2013), mengatakan bahwa psikoanalisis adalah disiplin ilmu yang dimulai sekitar tahun 1900-an oleh Sigmund Freud dan teori ini

Konflik Batin Tokoh "Aku” dalam Novel Garis Waktu Karya Fiersa Besari 
berhubungan dengan fungsi dan perkembangan mental manusia. Sementara Susanto (2012) menyatakan bahwa psikoanalisis memusatkan perhatiannya pada satu konsep, yakni ketidaksadaran.

Irwanto (1997) menyatakan pengertian konflik adalah keadaan munculnya dua atau lebih kebutuhan pada saat yang bersamaan. Konflik batin merupakan konflik yang dikarenakan adanya perlawanan dari diri sendiri dalam mengontrol diri sehingga dapat berpengaruh pada perbuatan atau perilaku. Konflik batin biasanya dapat menggangu kenyamanan atau ketenangan pikiran seseorang tersebut. Hal ini selalu terjadi kepada seseorang yang mengalami masalah pribadi ataupun yang lain namun masalah tersebut tidak ada penyelesaiannya.

Selanjutnya, Sayuti (2000), mengatakan bahwa konflik dalam diri seorang tokoh biasanya berupa perjuangan seorang tokoh dalam melawan dirinya sendiri, sehingga dapat mengatasi dan menentukan apa yang akan dilakukannya. Adapun konflik batin yang terjadi, bisa dilihat dari tokoh "aku" dalam isi cerita yang terdapat pada novel Garis Waktu karya Fiersa Besari.

Secara umum konflik dalam karya sastra dapat digolongkan menjadi dua jenis, yakni konflik internal dan konflik eksternal. Konflik internal adalah permasalahan yang terjadi dalam diri seseorang tokoh yang mengalami pergulatan dalam dirinya sendiri tanpa disebabkan atau dipengaruhi orang lain disekitarnya. Sedangkan konflik eksternal adalah permasalahan yang tejadi karena faktor lain di luar diri sang tokoh. (Sehandi, 2016)

Namun, Emzir \& Rohman (2016) mengemukakan bahwa konflik bisa di bagi menjadi tiga jenis. Pertama, konflik dalam diri seseorang (tokoh), konflik tersebut sering disebut juga psychological conflict atau konflik kejiwaan. Konflik jenis ini biasanya terjadi musabab suatu pertarungan individual atau perjuangan seorang tokoh dalam melawan dirinya sendiri, sampai pada akhirnya dia dapat mengatasi dan menemukan apa yang mesti dilakukanya. Kedua, konflik antara orang-orang atau seseorang dan masyarakat.
Konflik tersebut acap disebut dengan istilah social conflict atau konflik sosial. konflik seperti ini biasanya terjadi antara tokoh dengan lingkungan sekitarnya. Konflik tersebut timbul dari sikap individu terhadap lingkungan sosial dan menyangkut pelbagai masalah yang terjadi pada masyarakat. Ketiga, konflik antara manusia dan alam. Konflik seperti ini sering disebut juga sebagai physical or element conflict atau konflik alamiah. Jenis konflik ini biasanya terjadi ketika tokoh tidak bisa menguasai dan/atau memanfaatkan serta membudayakan alam sekitar sebagaimana semestinya. Apabila hubungan manusia dengan alamnya tidak serasi, maka akan terjadi disharmoni yang dapat menyebabkan terjadinya konflik tersebut.

Penelitian ini bukanlah penelitian yang baru ada. Oleh karena itu, penulis menggunakan penelitian yang relevan dengan kajian ini sebagai kontribusi atau manfaat kajian ilmiah. Berikut penelitian relevan yang penulis gunakan.

Penelitian relevan pertama dalam penelitian ini adalah Novel Negeri 5 Menara Karya Ahmad Fuadi Sebagai Bahan Ajar Sastra Indonesia Di SMA yang ditulis oleh Arif Wicaksono, Nas Haryati S., dan Sumartini yang terbitkan dalam Jurnal Sastra Indonesia, volume 3, nomor 1, Juni 2014. Hasil penelitiannya menunjukkan bahwa novel Negeri 5 Menara karya Ahmad Fuadi memperlihatkan unsur intrinsik, memenuhi aspek kesahihan, dan aspek kesesuaian yang menjadi kriteria bahan ajar sastra yang baik, sehingga novel Negeri 5 Menara karya Ahmad Fuadi ini dapat dijadikan sebagai pilihan bahan ajar sastra Indonesia di SMA.

Penelitian relevan kedua adalah artikel berjudul Kepribadian Tokoh Utama Vitkor Larenz dalam Roman Die Therapie Karya Sebastian Fitzek : Teori Psikoanalisis Freud yang ditulis oleh Putri Dyah Wahyu Puspita Sari, Jurusan Pendidikan Bahasa Jerman, Fakultas Bahasa dan Seni, Universitas Negeri Yogyakarta, tahun 2016. Hasil penelitian ini menunjukkan bahwa kepribadian tokoh utama Viktor Larenz dalam Roman Die Therapie karya Sebastian Fitzek dapat ditarik kesimpulan sebagai berikut struktur kepribadian tokoh utama Viktor Larenz

Konflik Batin Tokoh "Aku” dalam Novel Garis Waktu Karya Fiersa Besari 
memperlihatkan bahwa kepribadian Viktor Larenz dipengaruhi oleh id, ego, dan superego.

Penelitian relevan ketiga adalah Analisis Psikologis Tokoh Utama Novel Negeri 5 Menara Karya Ahmad Fuadi yang ditulis oleh Wira Fitria Atnur yang diterbitkan di jurnal of residu, volume 3, nomor 1, Agustus 2019. Hasil analisis menunjukkan bahwa pada novel Negeri 5 Menara mengemukakan psikologis tokoh utama, yaitu Alif yang memiliki ego lebih banyak dibandingkan dengan id dan super ego. Dengan lebih banyaknya ego yang dimiliki oleh tokoh utama Alif maka menunjukkan bahwa psikologis tokoh utama tersebut seimbang karena ego berfungsi menjembatani tuntutan id atau dalam diri dengan realitas di dunia luar.

\section{METODOLOGI PENELITIAN}

Jenis penelitian ini merupakan penelitian kualitatif. Metode penelitian ini merupakan deskriptif analitis. Sesuai pendapat Ratna (2006) menyatakan bahwa deksriptif analitis adalah upaya mendeskripsikan atau menggambarkan fakta-fakta kemudian disusul dengan analisis. Teknis atau metode yang berusaha untuk menggambarkan terhadap sesuatu yang akan dikritisi melalui data yang didapat lalu melakukan ulasan bahkan pembahasan. Sumber data diambil dari novel yang berjudul Garis Waktu karya Fiersa Besari. Data penelitian adalah berupa penggalan cerita-cerita berupa dimensi kewacanaan berupa kalimat-kalimat dialog tokoh yang mengindikasikan konflik batin tokoh "aku" dalam novel GW.

Dalam memperoleh data penelitian, peneliti menggunakan teknik pengumpulan data yakni teknik dokumentasi. Teknik ini dilakukan dengan cara menganalisis konflik batin pada tokoh "aku" dalam novel Garis Waktu. Teknik ini digunakan dan diaplikasikan melalui pengumpulan data yang signifikan dengan masalah penelitian. Unsur bahasa dibaca, diasumsi bahkan diulas melalui definisi secara saksama, sehingga memperoleh hasil penelitian konfik batin tokoh "aku" yang terdapat pada isi novel tersebut. Teknik analisis data dengan cara mendeskripsikan data, membahas hasil dan membuat simpulan.

\section{HASIL DAN PEMBAHASAN}

Penelitian ini mengungkapkan konflik batin pada tokoh "aku" yang terdapat pada novel Garis Waktu karya Fiersa Besari. Peneliti mengambil kutipan-kutipan dialog yang terdapat pada novel yang dihubungkan dengan konflik batin seorang tokoh "aku" dalam kajian psikoanalisis, yaitu kajian yang berupaya untuk menerangkan dasar dan perkembangan karakter manusia aspek kejiwaannya. Berdasarkan pengkajian, terdapat data-data yang berhubungan dengan konflik batin seorang tokoh "aku". Berikut kutipan dialog dan deskripsi data dari hasil penelitian yang berkaitan dengan konflik batin tokoh 'aku'.

Tabel 1. Konflik batin "aku" dalam novel GW karya Fiersa Besari

\begin{tabular}{|c|c|c|}
\hline No. & $\begin{array}{l}\text { Sub-Bab } \\
\text { dan } \\
\text { (Halama } \\
\text { n) } \\
\end{array}$ & Data \\
\hline 1. & $\begin{array}{l}\text { Dimensi } \\
\text { Tentangm } \\
\text { u (7) }\end{array}$ & $\begin{array}{l}\text { "Pernahkah kau ada di } \\
\text { titik dimana hidup begitu } \\
\text { teratur, melakukan segala } \\
\text { yang kau mampu untuk } \\
\text { menjadi seragam, } \\
\text { berharap semua akan } \\
\text { baik-baik adanya, namun } \\
\text { tetap merasa ada yang } \\
\text { hilang? Seolah, ada satu } \\
\text { kepingan puzzle yang tak } \\
\text { juga melengkapi teka teki } \\
\text { yang kau ciptakan } \\
\text { sendiri." }\end{array}$ \\
\hline 2. & $\begin{array}{l}\text { Perjumpa } \\
\text { an yang } \\
\text { Sederhana } \\
(11)\end{array}$ & $\begin{array}{l}\text { "Kota ini sedang di landa } \\
\text { gerimis tatkala jalan } \\
\text { hidupku ditakdirkan untuk } \\
\text { berubah selamanya. Ada } \\
\text { mata mu yang pertama } \\
\text { kali berbicara, menembus } \\
\text { pertahananku secara } \\
\text { mambabi buta. Kau } \\
\text { diamkan tanganku di } \\
\text { dalam jabatanku selama } \\
\text { beberapa detik. Aku } \\
\text { idamkan tanganku di } \\
\text { dalam genggaman mu } \\
\text { untuk selamanya." }\end{array}$ \\
\hline 3. & $\begin{array}{l}\text { Sesuatu } \\
\text { yang }\end{array}$ & $\begin{array}{l}\text { "Setelah perkenalan kita } \\
\text { kala itu, aku berharap }\end{array}$ \\
\hline
\end{tabular}

Konflik Batin Tokoh "Aku” dalam Novel Garis Waktu Karya Fiersa Besari 


\begin{tabular}{|c|c|c|c|c|c|}
\hline & $\begin{array}{l}\text { tumbuh } \\
\text { diam- } \\
\text { diam }(15)\end{array}$ & $\begin{array}{l}\text { segalanya akan kembali } \\
\text { normal. Kau kembali } \\
\text { kelangit } \\
\text { semestinya bintang berada } \\
\text { dan aku kembali ke bumi, } \\
\text { tenggelam dalam } \\
\text { rutinitas. Hidupku selama } \\
\text { ini sudah teramat tenang } \\
\text { dan aku tidak ingin secuil } \\
\text { adegan perkenalan }\end{array}$ & & & $\begin{array}{lr}\text { mana } & \text { datangnya? } \\
\text { Mengapa aku tidak } \\
\text { melihatnya } & \text { datang" } \\
\text { tampaknya, terlalu rapi } \\
\text { kau } & \text { sembunyikan } \\
\text { musuhku di dalam } \\
\text { selimutmu } \text { (siapa pun } \\
\text { yang } \\
\text { merenggutmu akan ku kaha } \\
\text { anggap musuhku)". }\end{array}$ \\
\hline & & $\begin{array}{l}\text { denganmu menjadi epek } \\
\text { kupu-kupu yang merusak } \\
\text { banyak rencana ku di } \\
\text { masa depan." }\end{array}$ & \multirow[t]{2}{*}{7.} & \multirow[b]{2}{*}{$\begin{array}{l}\text { Kalau } \\
\text { Saja Aku } \\
\text { Mampu } \\
(35)\end{array}$} & \multirow{2}{*}{$\begin{array}{l}\text { "Kalau saja aku mampu, } \\
\text { sudah ku kejar langkahmu } \\
\text { agar kita berjalan } \\
\text { berdampingan. Kalau saja } \\
\text { aku mampu, sudah } \\
\text { kuhiasi hari-harimu } \\
\text { dengan penuh senyuman. } \\
\text { Kalau saja aku mampu, } \\
\text { sudah kutemani dirimu } \\
\text { saat di rundung } \\
\text { kesedihan. Kalau saja aku } \\
\text { mampu, sudah kupastikan } \\
\text { bahwa aku pantas kau } \\
\text { sandingkan." }\end{array}$} \\
\hline \multirow[t]{2}{*}{4.} & \multirow[t]{2}{*}{$\begin{array}{l}\text { Sesuatu } \\
\text { yang } \\
\text { Tumbuh } \\
\text { Diam- } \\
\text { diam (16) }\end{array}$} & \multirow{2}{*}{$\begin{array}{l}\text { "Dan, aku hanya mampu } \\
\text { menjadi korban dari } \\
\text { kerinduan yang mencekik, } \\
\text { yang tersenyum dengan } \\
\text { pipi merah merona tatkala } \\
\text { kau menyapaku. Bak } \\
\text { anak kecil menemukan } \\
\text { mainan yang paling } \\
\text { diidamkan, } \\
\text { memimpikanmu terasa } \\
\text { menyenangkan, meski } \\
\text { kau hanya dapat ku } \\
\text { pandangi dari luar } \text { etalase. }\end{array}$} & & & \\
\hline & & & \multirow[t]{2}{*}{8.} & \multirow[b]{2}{*}{$\begin{array}{l}\text { Zona } \\
\text { Perteman } \\
\text { an }(43)\end{array}$} & \multirow{2}{*}{$\begin{array}{l}\text { "Aku tidak mau } \\
\text { berdrama, tapi aku tidak } \\
\text { bisa mengeluarkanmu dari } \\
\text { kepalaku. Aku tergila-gila } \\
\text { hingga tak tau lagi mesti } \\
\text { berbuat apa. Ini semacam } \\
\text { hasrat purba yang lebih } \\
\text { tua dari manusia. Jika kau } \\
\text { percaya akan jodoh } \\
\text { mungkin ini adalah } \\
\text { contohnya." }\end{array}$} \\
\hline 5. & \multirow[t]{2}{*}{$\begin{array}{l}\text { Dan } \\
\text { Kemudian } \\
(23)\end{array}$} & \multirow{2}{*}{$\begin{array}{lr}\text { "Pagi datang } & \text { lagi, } \\
\text { membangunkanku dengan } \\
\text { kicauan burung } & \text { dan } \\
\text { mentarinya. Hari yang } \\
\text { berbeda, waktu yang } \\
\text { berbeda, masa yang } \\
\text { berbeda. Masih dengan } \\
\text { perasaan yang sama yang } \\
\text { menunggu pesan darimu } \\
\text { masuk kedalam ponselku. } \\
\text { Sekedar selamat pagi } \\
\text { akan menjadi dua kata } \\
\text { paling hebat untuk } \\
\text { mengawali hariku." }\end{array}$} & & & \\
\hline & & & \multirow[t]{2}{*}{9.} & \multirow[b]{2}{*}{$\begin{array}{l}\text { Di Pukul } \\
\text { Mundur } \\
(47)\end{array}$} & $\begin{array}{lrr}\text { "Apakah tangis masih } \\
\text { menghiasi } & \text { pelupuk } \\
\text { matamu? Apakah lara } \\
\text { masih } & \text { menaungi } \\
\text { keseharianmu? Aku harap } \\
\text { kau belajar lagi }\end{array}$ \\
\hline \multirow[t]{2}{*}{6.} & \multirow[t]{2}{*}{$\begin{array}{l}\text { Ketika Ku } \\
\text { Kira Aku } \\
\text { Istimewa } \\
\text { (31) }\end{array}$} & \multirow{2}{*}{$\begin{array}{l}\text { "Masih kurangkah telinga } \\
\text { ini mendengar keluh } \\
\text { kesah? belum cukupkah } \\
\text { waktuku untuk membalas } \\
\text { segala aduanmu? Jika aku } \\
\text { yang kau rasa } \\
\text { menenangkanmu, lantas } \\
\text { mengapa ia yang } \\
\text { menenangkanmu? Siapa } \\
\text { gerangan dirinya? Dari }\end{array}$} & & & $\begin{array}{lr}\text { berbahagia. } & \text { Jangan } \\
\text { khawatir mengenai } \\
\text { kabarku, aku masih } \\
\text { mencoba baik-baik saja. } \\
\text { Memamerkan senyum } \\
\text { palsu, untuk seorang } \\
\text { badut sepertiku, adalah } \\
\text { hal biasa". }\end{array}$ \\
\hline & & & 10. & $\begin{array}{l}\text { Ketika } \\
\text { Duniamu }\end{array}$ & $\begin{array}{l}\text { "Kudengar seseorang } \\
\text { berhasil menghancurkan }\end{array}$ \\
\hline
\end{tabular}

Konflik Batin Tokoh "Aku” dalam Novel Garis Waktu Karya Fiersa Besari 


\begin{tabular}{|c|c|c|c|c|c|}
\hline & $\begin{array}{l}\text { Hancur } \\
\text { Berkeping } \\
\text {-keping }\end{array}$ & $\begin{array}{lrr}\text { hatimu. } & \text { Hampir saja aku } \\
\text { yang } & \text { terbiasa } & \text { yang } \\
\text { bertepuk } & \text { sebelah tangan }\end{array}$ & & & aku menyayangimu." \\
\hline & & $\begin{array}{l}\text { ini bertepuk tangan } \\
\text { sambil memuji-muji } \\
\text { karma. Tapi mana } \\
\text { mungkin aku tega } \\
\text { melihatmu berduka? } \\
\text { Orang bodoh macam apa } \\
\text { yang membiarkanmu } \\
\text { terluka?" }\end{array}$ & 14 & \multirow{2}{*}{$\begin{array}{l}\text { Serangkai } \\
\text { n Kode } \\
(80)\end{array}$} & \multirow{2}{*}{ 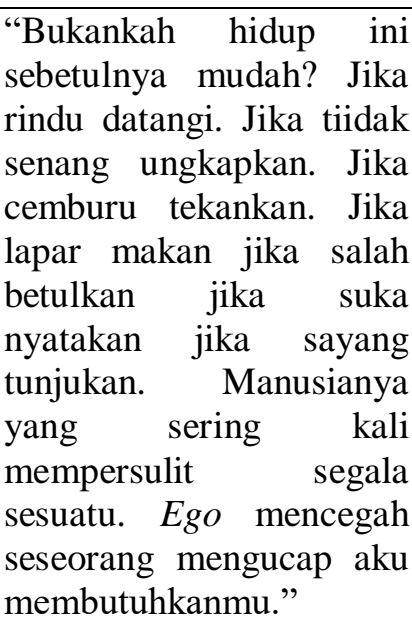 } \\
\hline \multirow[t]{2}{*}{11.} & \multirow[t]{2}{*}{$\begin{array}{l}\text { Pelarian } \\
(55)\end{array}$} & \multirow{2}{*}{$\begin{array}{l}\text { "Aku selalu menganggap } \\
\text { rela menunggu seseorang } \\
\text { tidak berarti bodoh, itu } \\
\text { hanya bearti teguh } \\
\text { pendirian. Karena sekuat } \\
\text { apapun kita menyangkal } \\
\text { sesuatu yang dikatakan } \\
\text { oleh hati, sekuat itu pula } \\
\text { hati kita akan berusaha } \\
\text { mendesak." }\end{array}$} & & & \\
\hline & & & 15. & \multirow{2}{*}{$\begin{array}{l}\text { Sesuatu } \\
\text { yang } \\
\text { Tertinggal } \\
\text { (83) }\end{array}$} & $\begin{array}{l}\text { "Bicara mengenai } \\
\text { komitmen, aku pernah } \\
\text { takut dengan komitmen. } \\
\text { Aku takut dengan kata }\end{array}$ \\
\hline \multirow[t]{3}{*}{12.} & \multirow{3}{*}{$\begin{array}{l}\text { Menjadik } \\
\text { anmu } \\
\text { Poros } \\
\text { Semesta } \\
(63)\end{array}$} & \multirow{3}{*}{$\begin{array}{l}\text { "Lalu, terlalu tinggikah } \\
\text { harapanku jika ingin } \\
\text { bersanding disebelahmu? } \\
\text { Aku tau aku tidak mahir } \\
\text { berkata-kata, tapi aku tau } \\
\text { cara mendoakanmu aku } \\
\text { tidak mahir memimpin } \\
\text { tapi aku tau cara } \\
\text { menuntunmu. Aku tidak } \\
\text { mahir melawak, tapi aku } \\
\text { tau cara membuatmu } \\
\text { bahagia. Aku tidak bisa } \\
\text { menjanjikan apapun tapi } \\
\text { selama aku mampu } \\
\text { mimpi-mimpi kita adalah } \\
\text { prioritas. Oleh karena itu, } \\
\text { maukah kah bersanding } \\
\text { denganku? }\end{array}$} & & & $\begin{array}{l}\text { menikah, takut dengan } \\
\text { ikatan monogami seiya } \\
\text { sekata sehidup semati." }\end{array}$ \\
\hline & & & 16 & $\begin{array}{l}\text { Rencana } \\
\text { Indah } \\
(87)\end{array}$ & $\begin{array}{lr}\text { "Aku } & \text { akan } \\
\text { mendampingimu ketika } \\
\text { flu membuat hidungmu } \\
\text { merah. Aku akan } \\
\text { mendampingimu sewaktu } \\
\text { kau sedih dan penuh } \\
\text { marah. Aku juga akan } \\
\text { medampingimu sewaktu } \\
\text { kau bahagia dengan } \\
\text { senyum mereka. Aku } \\
\text { akan mendampingimu } \\
\text { saat kau sibuk dengan } \\
\text { tugas kuliah." }\end{array}$ \\
\hline & & & \multirow[t]{2}{*}{17.} & \multirow[b]{2}{*}{ Akar (91) } & \multirow[b]{2}{*}{$\begin{array}{l}\text { "Jika kau bertanya siapa } \\
\text { superhero idolaku semasa } \\
\text { kecil, aku akan menjawab } \\
\text { superman. Namun, jika } \\
\text { kau bertanya siapa } \\
\text { superhero idolaku hari } \\
\text { ini, aku akan menjawab } \\
\text { orang tuaku. Mereka tidak } \\
\text { punya tujuh baja tapi } \\
\text { mereka mempunyai hati } \\
\text { sekuat baja, tapi mereka } \\
\text { bersedia menopang agar } \\
\text { aku mampu terbang dan } \\
\text { meraih mimpi." }\end{array}$} \\
\hline 13 & $\begin{array}{l}\text { Dimensi } \\
\text { Setelah } \\
\text { Kedatang } \\
\text { anmu (72) }\end{array}$ & $\begin{array}{l}\text { "Jika kata sayang terlalu } \\
\text { berlebihan } \\
\text { memaparkan apa yang } \\
\text { aku rasakan, biarkan aku } \\
\text { menjadi seseorang yang } \\
\text { menjagamu ketika kau } \\
\text { rapuh, dan menarikmu } \\
\text { turun ketika kau terlalu } \\
\text { angkuh.akan tetapi jika } \\
\text { kata sayang tidak } \\
\text { berlebihan } \\
\text { izinkanlah aku mengucap }\end{array}$ & & & \\
\hline
\end{tabular}

Konflik Batin Tokoh "Aku" dalam Novel Garis Waktu Karya Fiersa Besari 


\begin{tabular}{|c|c|c|c|c|c|}
\hline \multirow[t]{2}{*}{18.} & \multirow[t]{2}{*}{$\begin{array}{l}\text { Apakah } \\
\text { Hidupku } \\
\text { Sudah } \\
\text { Cukup } \\
\text { Berarti } \\
\text { (99) }\end{array}$} & \multirow[t]{2}{*}{$\begin{array}{l}\text { "Beberapa hari terakhir, } \\
\text { aku sering merenungkan } \\
\text { kematian. Kematian tidak } \\
\text { pernah membuatku takut. } \\
\text { Namun jujur saja, } \\
\text { memikirkan tentang " } \\
\text { bagaimana aku mati" } \\
\text { membuat bulu kudukku } \\
\text { meremang. Bagaimana } \\
\text { cara meninggal kelak? } \\
\text { Menghirup gas di gunung } \\
\text { layaknya Soe Hok gie? } \\
\text { Memuntahkan peluru ke } \\
\text { kepala sendiri semacam } \\
\text { Kurt Cobain? Diracun di } \\
\text { udara seperti Munir?". }\end{array}$} & & & $\begin{array}{l}\text { singkat berisi kata-kata } \\
\text { manis untuknya, juga } \\
\text { kemesraan kalian, sudah } \\
\text { menjadi bukti yang cukup } \\
\text { untuk menghancurkan apa } \\
\text { yang pernah kita punya } \\
\text { hatimu membelah diri. } \\
\text { Lantas, untuk apa aku } \\
\text { mati-matian menjaga } \\
\text { janji? Jijik! Aku mual } \\
\text { membayangkan apa yang } \\
\text { kalian lakukan di } \\
\text { belakangku." }\end{array}$ \\
\hline & & & \multirow[t]{3}{*}{22.} & \multirow{3}{*}{$\begin{array}{l}\text { Kembali } \\
\text { Menjadi } \\
\text { Anak } \\
\text { Kecil } \\
(169)\end{array}$} & \multirow{3}{*}{$\begin{array}{l}\text { "Aku ingin kembali } \\
\text { menjadi anak kecil , } \\
\text { dimana segalanya begitu } \\
\text { sederhana. Rasa dan raga } \\
\text { tak perlu saling } \\
\text { berlawanan. Bibir dan } \\
\text { kalbu tak perlu saling } \\
\text { tentang. Berkelahi kaena } \\
\text { main petak umpet, bukan } \\
\text { karena perasaan. Yang } \\
\text { diperebutkan adalah } \\
\text { mobil-mobilan, bukan } \\
\text { pacar orang lain. Yang } \\
\text { dikoleksi adalah robot- } \\
\text { robotan, bukan mantan } \\
\text { kekasih. Bersedih karena } \\
\text { putus benang layangan, } \\
\text { bukan karena putus cinta. } \\
\text { Menangis karena melukai } \\
\text { lutut, bukan karena } \\
\text { melukai hati”. }\end{array}$} \\
\hline 19. & $\begin{array}{l}\text { Jarak Pun } \\
\text { Mencoba } \\
\text { Peruntung } \\
\text { annya } \\
(109)\end{array}$ & 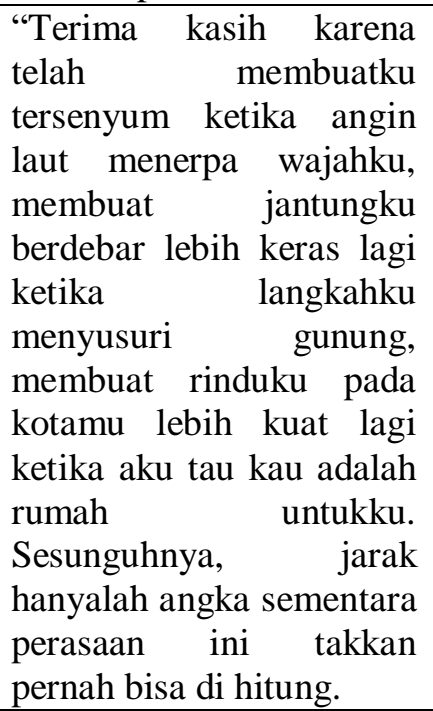 & & & \\
\hline \multirow[t]{2}{*}{20.} & \multirow[b]{2}{*}{$\begin{array}{l}\text { Genap } \\
\text { yang } \\
\text { Semakin } \\
\text { Ganjil } \\
(128)\end{array}$} & \multirow[b]{2}{*}{$\begin{array}{l}\text { "semakin hari kita } \\
\text { semakin tidak mengerti } \\
\text { satu sama lain. Bukan } \\
\text { karna kita benar-benar tak } \\
\text { mengerti, melainkan } \\
\text { karena kau memilih untuk } \\
\text { sulit dimengerti. Semakin } \\
\text { hari aku semakin takut } \\
\text { dengan realitas bahwa } \\
\text { kita memang akan } \\
\text { berakhir sedih. Dan aku } \\
\text { benci itu." }\end{array}$} & & & \\
\hline & & & 23. & $\begin{array}{l}\text { Bolehkah } \\
\text { Sehari Ini } \\
\text { Saja Aku } \\
\text { Menangis } \\
?(185)\end{array}$ & $\begin{array}{l}\text { "Aku menyesal betapa } \\
\text { aku tidak pernah cukup } \\
\text { menunukkan rasa hormat, } \\
\text { betapa aku terlalu sibuk } \\
\text { untuk ibadah berjamaah } \\
\text { dengannya, betapa aku } \\
\text { selalu menghindar saat } \\
\text { beliau butuh teman cerita, } \\
\text { betapa aku tidak pernah } \\
\text { tau beratnya sakit yang }\end{array}$ \\
\hline \multirow[t]{2}{*}{21.} & \multirow[b]{2}{*}{$\begin{array}{l}\text { Tatkala } \\
\text { Pedangm } \\
\text { u } \\
\text { Menghun } \\
\text { us } \\
\text { Jantungku } \\
(135)\end{array}$} & \multirow[b]{2}{*}{$\begin{array}{l}\text { "Lalu kau tertawa dan } \\
\text { berkata, aku tidak akan } \\
\text { pernah membohongimu } \\
\text { sayang. Kini aku tau } \\
\text { bahwa kata-kata itu } \\
\text { adalah } \\
\text { terbesarmu. } \\
\text { kebohongan } \\
\text { Pesan-pesan }\end{array}$} & & & beliau bawa". \\
\hline & & & 24. & $\begin{array}{l}\text { Sahabat } \\
(189)\end{array}$ & $\begin{array}{l}\text { "ketika aku hancur dan } \\
\text { kehilangan arah para } \\
\text { sahabat } \\
\text { menyelamatkanku. } \\
\text { Mereka memberitauku } \\
\text { bahwa mang }\end{array}$ \\
\hline
\end{tabular}

Konflik Batin Tokoh "Aku” dalam Novel Garis Waktu Karya Fiersa Besari 


\begin{tabular}{|l|l|l|}
\hline & $\begin{array}{l}\text { bukanlah akhir dunia. } \\
\text { Mereka juga berkata } \\
\text { bahwa tak mengapa untuk } \\
\text { sejenak melarikan diri } \\
\text { asalkan tidak lupa arah } \\
\text { pulang." }\end{array}$ \\
\hline 25. & $\begin{array}{l}\text { "Pada suatu sore, tatkala } \\
\text { awan kelabu sedang luruh } \\
\text { bergemuruh datanglah } \\
\text { sepucuk surat berhias pita } \\
\text { emas terselit di pintu } \\
\text { rumahku. Ada namamu } \\
\text { dan namanya bersiap } \\
\text { mengikat janji untuk } \\
\text { selamanya. Sementara } \\
\text { aku, mantan kekasihmu } \\
\text { Surat } \\
\text { Undangan berbesar hati } \\
\text { (197) }\end{array}$ \\
$\begin{array}{l}\text { melihatnya } \\
\text { memboyongmu sebagai } \\
\text { hadiah termanis." }\end{array}$ \\
\hline
\end{tabular}

Berdasarkan dua puluh lima data dari setiap sub-bab pada novel, terdapat cerita dari kehidupan pribadi tokoh "aku" yang sangat menarik. Dari setiap kutipan, memiliki cerita yang menonjol dan saling berkaitan, sehingga dari data di atas, penulis mengambil dua puluh lima kutipan yang diulas secara deskriptif dengan menggunakan kajian psikoanalisis yang berhubungan dengan konflik batin. Berikut ini adalah deskripsi dari data penelitian di atas berjumlah dua puluh lima data yang diambil peneliti dari novel Garis Waktu.

\section{Dimensi Tentangmu}

Pada sub-bab ini, tokoh "aku" menceritakan bahwa pernahkah hidupnya berada di titik dimana hidup dia sesuai dengan keinginnya, yang mampu melakukan segala sesuatu dan ia berharap apa yang ia lakukan tersebut adalah yang terbaik untuk dirinya. Namun ia merasa ada yang hilang seolah-olah itu menjadi tekateki bagi dirinya sendiri.

\section{Perjumpaan yang Sederhana}

Terdapat kisah pada sub-bab ini, yaitu tentang perjumpaan yang sederhana merupakan awal dimulainya kisah asmara tokoh "aku" yang mengidamkan seorang gadis dari perjumpaan yang sederhana tersebut. Ia berharap sosok gadis tersebut adalah malaikat yang sedang menyamar dan ditakdirkan untuknya. Dan ia hanya bisa pasrah semoga perkenalannya berbuah manis.

\section{Sesuatu yang Tumbuh Diam-diam}

Pada sub-bab ini tokoh 'aku' mulai melupakan gadis impiannya tersebut ia menganggap, ia dan dirinya bagaikan langit dan bumi yang tak akan bisa bersatu. Sekarang hidupnya sudah tenang dan ia tak ingin ada pertemuan berikutnya di masa depan kelak untuk merusak segalanya..

\section{Sesuatu yang Tumbuh Diam-diam}

Pada sub-bab ini, tokoh "aku" merasa begitu tenang setelah tidak ingin lagi mengenal gadis itu, namun gadis itu kembali dan selalu menyapanya hingga membuat pikirannya buyar. Ternyata mereka bertemu lagi di tempat, waktu, dan situasi yang tidak terduga. Lalu, gadis tersebut pergi begitu saja dan tokoh " $A k u$ " menjadi korban dari kerinduan yang mencekiknya. Dirinya tersenyum dengan pipi merah merona menyapa.

\section{Dan Kemudian}

Pada sub-bab ini, tokoh "aku" masih mengharapkan gadis pujaan hatinya walaupun hanya sekedar pesan yang masuk melalui ponsel dengan kata selamat pagi, sudah menjadi dua kata paling bermakna untuk mengawali harinya. Namun, itu hanya sebuah harapannya saja.

\section{Ketika Ku Kira Aku Istimewa}

Pada sub-bab ini, adanya konflik batin yang dirasakan oleh tokoh "aku" yaitu perasaan sakit hati dan tidak terima akan hal yang dilakukan oleh gadis tersebut. Mengapa gadis tersebut sangat pandai bermain di belakang tokoh "aku" sehingga tokoh "aku" tidak menyadari bahwa wanita tersebut telah berkhianat dengan musuh tokoh "aku".

\section{Kalau Saja Aku Mampu}

Pada sub-bab ini, akibat tidak keberaniannya tokoh "aku" untuk mengungkapkan segala keinginannya pada gadis yang ia cintai. Tokoh "aku" hanya berdiam diri dan memandangi wajah gadis tersebut tanpa berbicara sedikitpun. Padahal 
kalau saja tokoh "aku" mampu mengungkapkan perasaannya, pasti gadis tersebut akan menjadi miliknya.

\section{Zona Pertemanan}

Pada sub-bab Zona Pertemanan, menceritakan tokoh "aku" sangat tergila-gila oleh gadis tersebut. Sehingga setiap hal yang dilakukan oleh tokoh " $A k u$ ", pikirannya selalu tertuju pada gadis itu dan hasrat untuk memilikinya. Tokoh "aku" selalu berharap bahwa jodohnya adalah gadis tersebut.

\section{Dipukul Mundur}

Tokoh "aku" yang berusaha mencoba untuk kuat dan tegar di hadapan gadis tersebut. Walaupun sebenarnya semua itu hanya bohong, tokoh "aku" merasa tidak berdaya karena melihat gadis itu bersama orang lain yang ia pilih.

\section{Ketika Duniamu Hancur Berkeping- keping}

Pada sub-bab ini, diceritakan bahwasanya tokoh "aku" tetap saja mau membantu dan mendengarkan keluh kesah gadis tersebut tentang laki-laki pilihannya walau telah berkali-kali disakiti oleh gadis tersebut.

\section{Pelarian}

Pada sub-bab Pelarian, tokoh "aku" menganggap menunggu itu bukanlah hal yang bodoh. Namun itu adalah sebuah tekad yang harus dilakukan demi seseorang yang ia cintai. Meski sekuat apapun tokoh "aku" tetap saja tidak mampu menyangkal bahwa ia sangat mencintai gadis tersebut. Walaupun hatinya sudah berkali-kali dipatahkan.

\section{Menjadikanmu Poros Semesta}

Pada sub-bab ini, tokoh "aku" menyatakan rasa cintanya dengan perasaan sedikit gugup kepada gadis itu dan melontarkan kata-kata manis untuk gadis tersebut. Namun, tokoh "aku" belum mendapatkan jawaban dari gadis itu.
Pada sub-bab ini, tokoh " $A k u$ " merasa senang karena keinginannya untuk memiliki gadis yang dicintainya sudah terwujud. Tokoh "aku" berharap akan selalu bersama gadis tersebut.

\section{Serangkaian Kode}

Pada sub-bab ini, tokoh "aku" sangat kecewa karena gadis tersebut tidak berterus terang bahwa gadis itu membutuhkan tokoh "aku".

\section{Sesuatu yang Tertinggal}

Pada sub-bab ini, tokoh "aku" merasa takut akan komitmen, karena sebelumnya dia pernah dikhianati oleh orang lain di masa lalunya. Apalagi dengan kata "menikah" yang berkomitmen sehidup semati, membuat rasa takut tokoh "aku" semakin besar.

\section{Rencana Indah}

Pada sub-bab ini, tokoh "aku" sangat senang dan sangat setia terhadap gadis pujaannya. Dalam hal apapun, tokoh "aku" selalu mendampingi gadis tersebut.

\section{Akar}

Pada sub-bab ini, tokoh "aku" sangat menyayangi orang tuanya. Tidak ada satupun yang bisa menggantikan posisi orang tuanya. Orang tuanya sangat hebat mempunyai hati sekuat baja meskipun rintangan selalu datang bertubi-tubi, orang tuanya tetap melakukan yang terbaik demi kebahagaan tokoh "aku" untuk meraih mimpi.

\section{Apakah Hidupku Sudah Cukup Berarti}

Pada sub-bab ini, tokoh "aku" tidak takut akan kematian. Namun, merasa takut dalam membayangkan bagaimana caranya ia mati dalam meninggalkan dunia ini.

\section{Jarak Mencoba Peruntungannya}

Pada sub-bab ini, tokoh "aku" menahan kerinduan akibat jarak. Namun, tokoh " $A k u$ " selalu mencoba menjelaskan kepada gadis tersebut bahwa jarak hanyalah angka. Sementara, perasaannya tidak akan pernah bisa dihitung. Sehingga hubungan mereka tetap bertahan.

\section{Genap yang Semakin Ganjil}

\section{Dimensi Setelah Kedatanganmu}


Pada sub-bab ini, tokoh "aku" merasa tertekan karena ia merasa curiga kepada gadis pujaannya. Tokoh "aku" tidak mengerti dengan sikap dan prilaku gadis tersebut. Bahkan, mereka sudah saling tidak mengerti sehingga tokoh "aku" merasa takut jika pada akhirnya hubungan mereka berakhir yang hal itu sangat tidak diinginkan olehnya.

\section{Tatkala Pedangmu Menghunus Jantungku}

Pada sub-bab ini, tokoh " $A k u$ " merasa marah karena gadis tersebut telah berbohong dan mengkhianati tokoh "aku". Tokoh "aku" tanpa sengaja membaca pesan singkat yang berisi kata manis dari laki-laki lain dan tidak sengaja melihat gadisnya bermesraan dengan laki-laki itu yang membuat hatinya menjadi sakit.

\section{Kembali Menjadi Anak Kecil}

Pada sub-bab ini, tokoh "aku" merasa senang saat dirinya kembali menjadi anak kecil. Karena menurutnya, saat itu ia merasa bebas melakukan hal apapun. Beda dengan sekarang yang telah dewasa yang selalu banyak pertimbangan yang terjadi dalam hidup, tidak sebebas saat menjadi anak kecil dulu.

\section{Bolehkah Sehari Ini Saja Aku Menangis?}

Pada sub-bab ini, tokoh "aku" merasa menyesal karena ia kurang menghargai Ayahnya. Sehingga pada suatu ketika, tokoh "aku" bermimpi ia mendapat firasat bahwa di dalam mimpinya ada seseorang yang akan pergi. Kemudian, keesokan harinya mimpi itu menjadi nyata yang ternyata Ayahnya meninggalkan dunia untuk selamanya.

\section{Hei, Sahabat}

Pada sub-bab ini, tokoh "aku" merasa hancur dan kehilangan arah. Namun saat itu sahabatnya yang membangkitkannya kembali. Segala cara dilakukan oleh sahabat tokoh "aku" untuk mengingatkan bahwa perpisahan bukanlah akhir dari segalanya dan yang hidup pasti akan mati. Akhirnya tokoh "aku" kembali sadar dan tidak ingin lagi larut dalam kesedihan.

\section{Sepucuk Surat Undangan}

Pada sub-bab ini, tokoh "aku" merasa tabah dan harus berbesar hati menerima semua keadaan ini. Tokoh "aku" harus rela menerima setelah mendapat sepucuk surat berhias pita emas di depan pintu rumahnya yang di dalam undangan tersebut berisi nama gadis masa lalunya dengan orang lain.

Berdasarkan hasil penelitian mendeskripsikan bahwa terdapat konflik batin tokoh "aku" dalam novel Garis Waktu. Pesan cerita yang terdapat pada novel ini sulit dipahami karena lebih banyak menggunakan kata-kata puitis yang mana kata-kata tersebut lebih cocok untuk puisi. Sebab penulis sulit memahami sehingga pesan yang terkandung hanya tersirat. Namun novel ini menjadi menarik karena kata-kata puitisnya tersebut.

Novel Garis Waktu karya Fiersa Besari ini sangat tepat dikaji menggunakan teori psikoanalisis yang berhubungan dengan konflik batin. Karena di dalam novel ini isinya berhubungan dengan teori yang diteliti yaitu menceritakan kisah asmara, keluarga, serta persahabatan, yang menjadi satu.

Konflik batin yang dihadapi oleh tokoh "aku" mencerminkan hubungan antara kepribadian dan karya sastra itu sendiri. Bilamana dikaitkan dengan konsep psikoanalisis bahwa deksripsi cerita menunjukkan pengarang dengan kualitas karyanya melalui kualitas nalar, kehidupan dan lingkungan pengarang sendiri sehingga memicu terjadinya konflik batin.

Selain itu, novel GW ini adalah cerminan pribadi dan perwatakan pengarang yang sebenarnya terjadi konsep dualisme kepribadian dalam kekaryaan. Dualisme ini sebagai hakikat seorang penulis dan pelaku dalam karya novel itu sendiri, kadang memang sulit mengungkapkan hal yang sifatnya pribadi menjadi suatu karya yang dapat dikonsumsi oleh masyarakat awam. Sehingga novel ini sebenarnya dapat dikatakan sebagai cerminan kepribadian pengarang itu sendiri. Namun sebagai hakikat kekarya-sastraan fenomenafenomena nilai estetika tetap ada dan dikedepankan melalui diksi-diksi puitis yang digunakan oleh pengarang.

Konflik Batin Tokoh "Aku" dalam Novel Garis Waktu Karya Fiersa Besari 


\section{SIMPULAN}

Berdasarkan pembahasan, maka simpulan penelitian ini adalah novel Garis Waktu ini diceritakan kehidupan pribadi seorang tokoh " $A k u$ " yang belum tahu akhir dari cerita kehidupannya. Jika dihubungkan dengan konflik batin dalam kajian psikoanalisis, pada setiap kutipannya novel ini sangat sesuai dengan kajian yang sedang diteliti.

Unsur pendukung terjadinya konflik batin 'Aku' didominasi oleh unsur dalaman atau jiwa tokoh itu sendiri yang dipicu adanya permasalahan-permasalahan eksternal sebagai titik tolok tercipta konflik.

Pada tokoh " $A k u$ " dalam novel Garis Waktu sebuah novel yang sangat menarik, sebab tidak hanya bertumpu pada satu cerita saja, yaitu cerita asmaranya, tetapi juga menceritakan cerita lainnya seperti cerita dirinya yang kurang peduli terhadap orang tuanya sehingga timbul sebuah rasa penyesalan. Dengan kata lain konsep sosial juga tergambar di novel ini. Sehingga konflik batin yang dihadapi juga berkaitan dengan orang lain.

Konflik batin tercermin melalui paparan data-data yang menggambarkan pergolakan batin tokoh sendiri, sehingga hal tersebut menjadi cerminan kepribadian si pengarang. Cerminan kepribadian ini dibalut dengan konsep puitis dan nilai-nilai estetika karya sastra.

\section{REFERENSI}

Arif Wicaksono, Nas Haryati dan Sumartini. (2014). Novel Negeri 5 Menara Karya Ahmad Fuadi Sebagai Bahan Ajar Di SMA. Jurnal Sastra Indonesia. 9. https://journal.unnes.ac.id/sju/index.p hp/jsi/article/view/3990. Diakses pada hari Senin, 4 Mei 2020, pukul 13.00.

Emzir \& Rohman. (2016). Teori dan Pengajaran Sastra. Jakarta: PT. Raja Grafindo Persada.

Hartati, Mesterianti. Penggambaran Watak Dalam Cerita Rakyat "Petualangan Pak Aloi" Karya Zainuddin Muhyid .Jurnal Pendidikan Bahasa, 8(1):103, Juni 2019
Husnah , Nadyatul, dkk. Novel Pergi Karya Tere Liye: Analisis Konflik Batin Tokoh Utama. Paramasastra, 6( 1):63, Maret 2019.

Irwanto. (1997). Psikologi Umum. Jakarta: PT. Gramedia Pustaka Utama.

Minderop, Albertine. (2013). Psikologi Sastra

“ Karya Sastra, Metode, Teori, dan Contoh Kasus." Jakarta: Yayasan Pustaka Obor Indonesia.

Miyasari, Tita Nurajeng. Kepribadian Tokoh Utama Dalam Cerpen Saga Karya Shantined Dari Kumpulan Cerpen Un Soir Du Paris: Kajian Psikoanalisis. Jurnal Gramatika, 6 (1):10-11, Juni 2018.

Nugroho dkk. Novel Burung-Burung Manyar Karya Y.B. Mangunwijaya Sebagai Materi Pembelajaran Sastra: Konflik Batin Dan Nilai Pendidikan Karakter. BASASTRA (Jurnal Bahasa, Sastra, dan Pengajarannya). 7( 2):104, Oktober 2019.

Nurgiyantoro. (2010). Teori Pengkajian Fiksi. Yogyakarta: Universitas Gadjah Mada Press.

Putri Dyah Wahyu Puspita Sari. (2016)."Kepribadian Tokoh Utama Viktor Larenz dalam Roman Die Therapie Karya Sebastian Fitzek : Teori Psikoanalisis Freud". Fakultas Bahasa dan Seni. Universitas Yogyakarta

Yogyakarta.https://eprints.uny.ac.id/ 33955/. Diakses pada hari Senin, 4 Mei 2020, pukul 13.10.

Ratna, Nyoman Kutha. (2006). Teori, Metode, dan Teknik Penelitian Sastra. Yogyakarta: Pustaka Pelajar.

Sayuti, Suminto A. (2000). Berkenalan dengan Prosa Fiksi. Yogyakarta: Gama Media.

Sehandi, Yohanes. (2016). Mengenal 25 Teori Sastra. Yogyakarta: Ombak Tiga.

Susanto, Dwi. (2012). Pengantar Teori Sastra. Yogyakarta: CAPS.

Walgito, Bimo. (1997). Psikologi Umum. Yogyakarta: Fakultas Psikologi UGM.

Wira Atnur Fitria. (2019). Analisis Psikologis Tokoh Utama Novel Negeri 5

Konflik Batin Tokoh "Aku” dalam Novel Garis Waktu Karya Fiersa Besari 
Menara Karya Ahmad Fuadi. Jurnal

Of Residu. 99-101.https://ojs.rc-

institut.id/index.php/education/article

/download/279/244. Diakses pada hari Senin, 4 Mei 2020 pukul 13.20.

Zaidan, Rozak Abdul. (2007). Kamus Istilah

Sastra. Jakarta: Balai Pustaka. 